\title{
Exploring the cognitive process of prospective mathematics teachers in constructing a graph
}

\author{
Dona Afriyani, Kurnia Rahmi Yuberta ${ }^{1}$
}

\begin{abstract}
Abstrak: Artikel ini bertujuan menganalisis strategi dan proses kognitif mahasiswa calon guru matematika dalam mengonstruksi grafik fungsi komposisi. Empat puluh empat calon guru menyelesaikan tugas konstruksi grafik (GCT) fungsi komposisi kemudian empat orang dipilih sebagai subjek. Data penelitian dikumpulkan melalui hasil kerja subjek pada GCT dan wawancara berdasarkan hasil kerja. Analisis data dimulai dengan mengelompokkan hasil konstruksi grafik oleh subjek dan membuat transkrip wawancara. Peneliti kemudian mengeksplorasi dan membuat kode hasil konstruksi grafik, menjelaskan strategi dan struktur proses kognitif subjek dalam mengonstruksi grafik, membuat tema berdasarkan strategi dan proses kognitif. Selanjutnya, peneliti menggunakan tabel, skema dan narasi untuk menampilkan dan melaporkan temuan penelitian, menafsirkan temuan penelitian dan melakukan validasi hasil penelitian dengan triangulasi sumber data. Kami menemukan (1) dua strategi yang digunakan oleh subjek dalam membangun grafik yaitu dengan-translasi dan tanpa-translasi; dan (2) proses translasi dalam mengonstruksi grafik dimulai dengan membongkar representasi sumber, koordinasi awal, membangun representasi target dan diakhiri dengan menentukan kesetaraan antara representasi sumber dan representasi target. Temuan menunjukkan bahwa ada variasi transfer dalam konten konseptual dari mikro konsep representasi sumber ke mikro konsep representasi target. Variasi disebabkan oleh perbedaan dalam jenis pemetaan yang dilakukan pada tahap koordinasi awal.
\end{abstract}

Kata kunci: Proses kognitif, Konstruksi grafik, Calon guru matematika, Fungsi komposisi

Abstract: This article aims to analyze the strategies and cognitive process of prospective mathematics teachers (PMTs) in constructing graphs of composition function. Forty-four PMTs participated in graph construction tasks (GCT) of composition function. Four of them were purposively selected as the subjects. Data were collected through subjects' works on GCT and interviews based on their works. Data analysis started with organizing subjects' construction of the graph and transcribing the results of the interview. We then explored and coded the subjects' constructed graphs, followed by describing the subjects' strategies and structure of the cognitive process of graph construction and establishing themes, representing and reporting the findings with tables, schemes and narratives, interpreting the findings, and validating the accuracy of the findings by triangulation of the data sources. We found (1) two strategies used by the subjects in constructing graph namely with-translation and without-translation; and (2) the translation process in constructing the graphs begins by unpacking the source representation, preliminary coordination, constructing the target representation and end with determining the equivalence between the source representation and the target representation. The findings indicate that there are transfer variations in conceptual content from micro-concepts of source representation to micro-concepts of target representation. The variations are caused by the differences in the types of mapping carried out at the initial coordination stage.

Keywords: Cognitive process, Graph construction, Prospective mathematics teacher, Composition function

\footnotetext{
${ }^{1}$ Institut Agama Islam Negeri (IAIN) Batusangkar, Sumatra Barat, Indonesia, donaafriyani@iainbatusangkar.ac.id
} 


\section{A. Introduction}

The graph is one of the external representations that are used to present, describe, and communicate mathematical concepts (Bossé, Adu-Gyamfi, \& Chandler, 2014; Higley, 2009). Adu-Gyamfi and Bossé (2013) explain that the graph has a convention between the horizontal axis ( $x$-axis) and the vertical axis ( $y$-axis) in a cartesian coordinate, abscissa-ordinate ordered pairs and the intersection with both coordinate axes. The elements of the graph structure builders provide information relating to ideas, concepts, and specific mathematical relationship. In order to extract information on the graph, several cognitive processes of reading and interpreting graphs builder elements are needed (Roth \& Bowen, 2001). In this context, graphs can be viewed as an object learnt by the students (Lowrie $\&$ Carmen, 2007) by performing specific cognitive processes.

In the context of learning mathematics, the graph is seen as an important process in building the process of mathematical thinking (Lowrie \& Carmen, 2007; NCTM, 2001). NCTM (2001) suggests that teachers can use graphs to clarify mathematical ideas and access to the mathematical thinking process. Barmby, Harries, Higgins, and Suggate (2007) assert that the graph as a manifestation of students' mental process visualization can be used to see the depth of mathematical understanding. The results of the activity of reading and graphs interpretation or otherwise translate the mathematical idea into a graph form can be a measure of the quantity, and quality understanding of mathematical concepts belong to a student.

Sketch or drawing graphs can facilitate students in the development of reasoning (Ruchti \& Bennett, 2013). This article prefers use the term "constructing" to "drawing" since constructing process is seen to be more active in developing the students' thinking process, whereas sketching is more dominant in students' skills domain. Some researchers (e.g., Morden-Sniper, Dai, Booth, Chang, Cromley \& Newcombe, 2015; Adu-Gyamfi \& Bossé, 2013) argue that there are several factors influence the success of constructing a mathematical representation. Morden-Snipper et al., (2015) found that cognitive factors and representation strategy have a significant influence on the success of constructing a mathematical representation. Furthermore, Adu-Gyamfi and Bossé (2013) disclose three factors in the construction of mathematical representation, namely representation register (micro-concept), mathematical domains, and domain register. AduGyamfi and Bossé (2013) explain that the micro-concept of graph representation comprises a certain number of ordered pairs of abscissae and ordered values linked by specific rules (conventions) on the perpendicular axis (Cartesian coordinates). The mathematical domain contains ideas, concepts, and features or procedures for a mathematical subject. In this article, the mathematical domain is composition function. Domain register is needed to see the interaction between micro-concept graphs and the concept of composition function.

Shah and Hoeffner (2002) conclude several research questions that have the potential to be further investigated in the construction of graph and have implication for instruction. They include the difficulties faced by students and the relationship between mathematical ability and graph construction. Carlson, Larsen, and Jacobs (2001) found that students are difficult in distinguishing visual attributes of the graph. Friel, Curcio, and Bright (2001) named four critical factors that affect the graph construction namely the purpose to use graph, task characteristics, the characteristics of the content/science disciplines and the reader characteristics. Diezman and Tom (2006) argue that the elements of mathematical content, graphics knowledge, and the context of mathematical literacy must be considered simultaneously to allow students to interpret graphs correctly. 
In relation to the research on the graph, prior researchers (e.g., Carlson et.al., 2001; Diezman \& Tom, 2006; Friel et.al., 2001; Morden-Snipper et.al., 2015; Shah \& Hoeffner, 2002) have investigated interpretation aspects of graph, understanding of graphs and factors that influence the success of graph construction. However, as far as our concern, not many studies have explored qualitatively on the cognitive processes of prospective teachers in constructing a graph in general and cognitive process of different strategies employed by PMTs in specific. A qualitative inquiry on mathematical activities which emerge in a graph construction is a necessity since it describes the whole cognitive process required in such task. The current study filled up the deficiency of study on related topic.

In our study, the graph is viewed as processes and object. As a process, graph is a mental configuration owned by the students, and it can be observed through a particular mathematical behavior (Goldin, 1998). The manifestation of mental configuration is in the form of mathematical ideas and the connections between those ideas. As an object, graph is a symbol system that has a convention between the $x$-axis and $y$-axis in a Cartesian coordinate, ordered pairs ordinate-abscissa and the intersection with both coordinate axes (Adu-Gyamfi \& Bossé, 2013; Duval, 2006). In this view, a graph is the result of the process. Thus, it can be said that constructing the graph is a mental activity that involves identifying, reading, interpreting, transferring mathematical concepts to graph builder elements (micro-concepts) and articulating the information on the graph. The activity of transferring mathematical concepts to graphic builder elements (micro-concepts) and articulating information on the graph occurs when students translate among mathematical representations. The translation is a cognitive process in changing the form of representation to another form (Adu-Gyamfi, Stiff, \& Bossé, 2012). Mathematical representations commonly used in learning functions consist of symbolic, verbal representations, graphs, and tables. The difference between the four representations is character or micro-concept. For example, micro-concepts of symbolic representation have characters namely coefficients, constants, variables, and operators "equal to" "more than" "less than" and basic mathematical operations (Duval, 2006).

The use of graph paradigm as the objects and process helps us to look at the quantity and quality of cognitive process about the concept of composition function through the task to construct a graph. The topic selection of the composition function concept is based on several considerations. First, the ability to understand the concept of composition function and the concept of composition function derivative is needed to understand the concept of the chain rule on differential (Jojo, 2014). Second, a good understanding of the composition function concept indicates the clarity of function components (Watson \& Harel, 2013), which consists of a convention between input and output. Third, the learning practice about composition function in secondary school and undergraduate so far does not use multiple representation strategy (Subanji, 2007)

In addition, most mathematics textbooks in undergraduate and secondary schools do not present how to understand the composition function through various representation forms (Subanji, 2007). It resulted in the understanding that the composition function is compartmentalized in the symbolic representation only. Elia and Spyrou (2006) call this a compartmentalization phenomenon, namely cognitive difficulties that arise because of a lack of coordination in forming a mathematical ideas or concepts network between two or more representation forms. This last consideration is an empirical fact that contradicts the suggestion of NCTM, namely using various representations in mathematics will support student's rich mathematical ideas or concepts and connections between those ideas (NCTM, 2001). This point 
is another rationale for the necessity of investigating the students'cognitive process in completing the task of constructing the composition function graph. The implications of this research will be used to improve teaching practices of composition function in mathematics teacher education, so the emergence of cognitive difficulties such as the phenomenon of compartmentalization can be avoided. In this article, we will discuss the questions: (1) How is the graph construction strategy done by the students? (2) How is the students' translation process constructing graphs of composition functions? The answers to these two questions will provide a more detailed and concrete description of the process of thinking or strategy in constructing the graph so that more visible types of cognitive processes are involved in constructing the graph.

\section{B. Methods}

We gave a task to construct the graph of composition function (Graph Construction Task, GCT) to forty-four prospective mathematics teachers (PMTs) who enrolled in the composition function course. From all the participants, four participants constructed the graph of composition function correctly and selected as the subjects in the research to be further interviewed. Their work represented all categories of PMTs' strategies in completing the construction of the graph. Three subjects (M1, M2, M4) represented PMTs who used translation strategy while one subject (M3) represents those who did not use translation strategies. Of three subjects who applied translation strategy, we only analyze two subjects' works (M1 and M2) in this paper since one subject (M4) has quite similar ways of constructing the graph with M1.

GCT (Table 1) aimed to explore the PMTs' strategies and cognitive process in completing the task. It has been declared valid by the validators. i.e experts on mathematics and mathematics education. The $f$ (quadratic function) and $g$ (piecewise linear function) were given, the students were asked to construct the graph $f \circ g$.

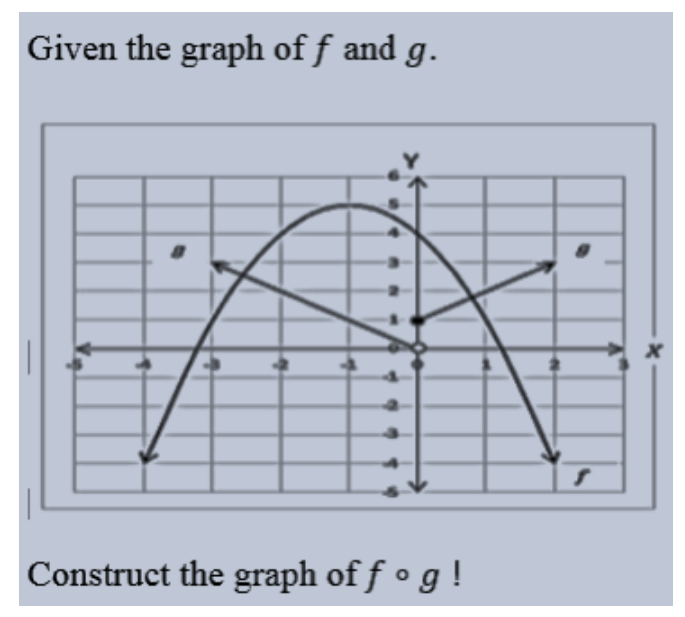

Figure 1. Graph construction tasks (GCT)

The research was qualitative-explorative. Data was collected through subjects' works on GCT and task-based interview. The interview data is a description of the subject's cognitive process when completing GCT. The process during the interview was documented using a video recorder. The questions are given to the subjects referred to a deeper dig into their cognitive process when completing the task. The students' works of completing the graph construction task of the composition function were grouped, and the pattern was identified. The pattern strategy found was used to track more details about the students' cognitive process in each pattern. The tracking of the cognitive process was conducted to four subjects by conducting task- 
based interview. The questions in the interview are (1) exploration of subjects' works, such as how you do it or find it? (2) confirmation of student cognitive processes in completing GCT, do you do this? are you sure of your answer? and (3) clarification of subjects' reasoning, why do you think like that?

Six steps were employed to analyze the research data (Creswell, 2012). First, preparing and organizing the data. In this step, we prepared students' works on GCT (the construction of composition function graphs) and recorded interview to be processed and organized. The students' works on GCT were organized into two types, i.e., correct and incorrect answers. For the need of exploring the cognitive process in completing GCT, we used students' correct work only. The recorded interview was verbatim transcribed. Second, exploring and coding the subjects' work on GCT. We thoroughly read and discussed the correct answers and transcripts then wrote a summary of the subjects' strategies in constructing the graphs and its cognitive process for each strategy. To uncover the subjects' cognitive process, each researcher coded the subjects' mathematical activities in completing GCT. The codes used were operators (such as arrows with different colors), and combination of letters and numbers. Operators refer to the cognitive process, meanwhile combination of letters and numbers refer to results obtained from the cognitive process. The coding results of each researcher were compared. If the results obtained were different, then re-coding were carried out. This activity kept repeating until saturated coding was found.

Third, describing findings and forming themes. We elaborated the subjects' strategies and the structure of cognitive processes in constructing the graphs. Two themes were generated from the results of elaboration, i.e., with-translation and without-translation. We referred to four translation mechanism by Bossé, et al., (2014) to explain subjects' translation stages. Meanwhile, without-translation did not refer to the mechanism, but it alluded to a cognitive process which emerged from the first to the last steps of constructing the graph. Fourth, representing and reporting findings. We created tables, schemes of cognitive process structures, and narratives to illustrate research findings. Fifth, interpreting the meaning of the findings. We analyzed interesting things from the research findings so that they could be explained about how the research questions were answered, the position of the research findings on prior research, and its limitations. And sixth, validating the accuracy of the findings. We checked the validity of data through triangulation of the data sources by looking back at the compatibility of the cognitive process between students' work and interview.

\section{Findings and Discussion}

Only four of forty-four PMTs were able to complete GCT correctly. The examples of subjects' work can be seen in Figure 1.a, Figure 1.b, and Figure 2.

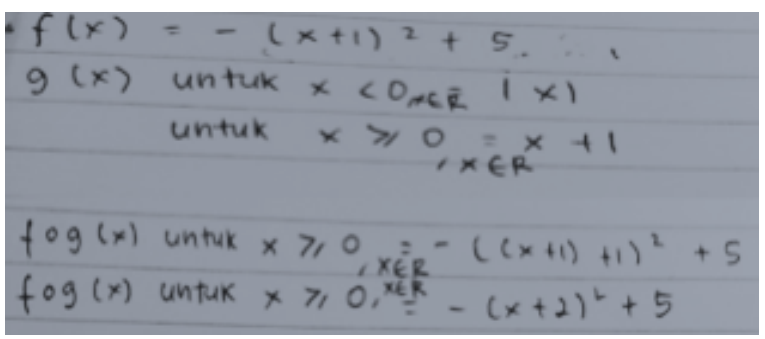

Figure 1.a. Examples of subject's (M1) work using the with-translation strategy: translation from the graph to symbolic $(\mathrm{G} \rightarrow \mathrm{S})$ 


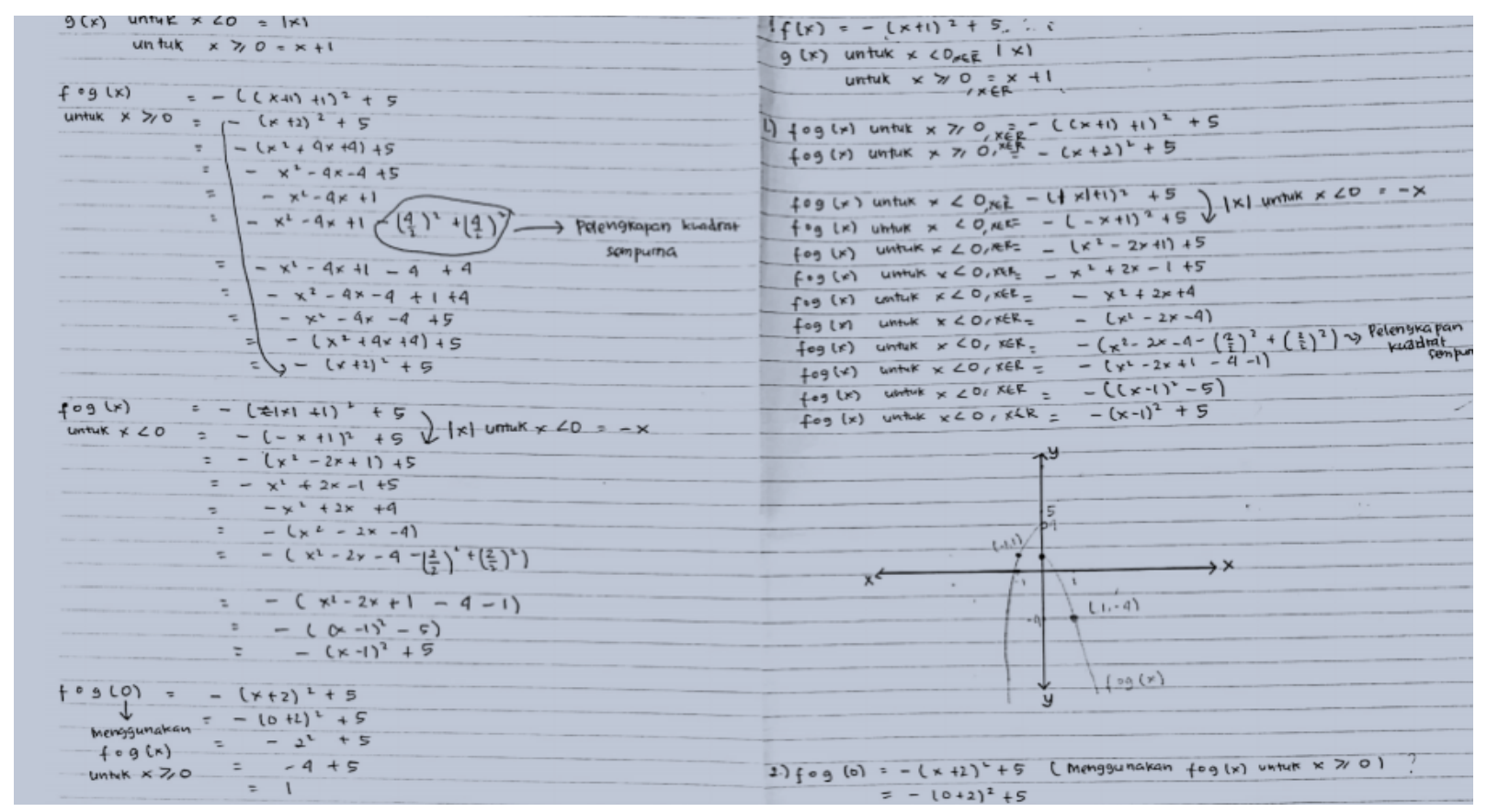

Figure 1.b. Examples of subject's (M1) work using the with-translation strategy: translation from the symbolic to graph $(\mathrm{S} \rightarrow \mathrm{G})$

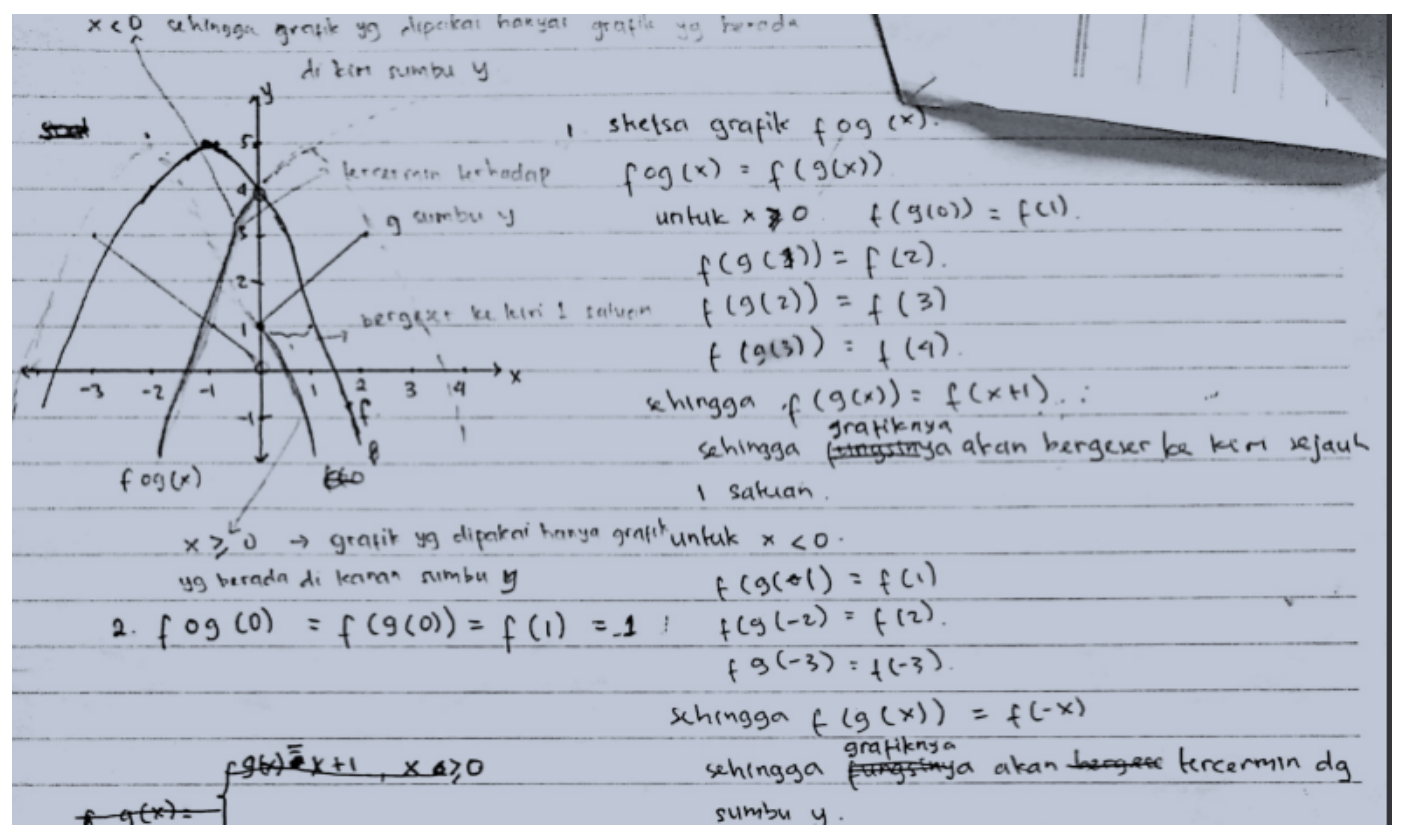

Figure 2. Examples of subject's (M3) work using the without-translation strategy

The subjects' works on GCT showed that there are two strategies used in constructing graphs of composition function, namely the with-translation and without-translation. Table 1 presents the percentage of each strategy with success and failure category to construct a graph. It reveals that most students experienced cognitive difficulties in completing GCT. The explanation of this difficulty was not a scope of discussion this article. Our findings are equipped with examples of subjects' work and interview responses to understand thoroughly the cognitive process of the subject in each strategy that successfully completes GCT. 
Table 1. Graph construction strategy and the frequency

\begin{tabular}{|c|c|c|c|}
\hline \multicolumn{4}{|c|}{ Strategy } \\
\hline \multicolumn{2}{|c|}{ With-translation } & \multicolumn{2}{|c|}{ Without-translation } \\
\hline Success & Failure & Success & Failure \\
\hline 3 & 36 & 1 & 4 \\
\hline $6,82 \%$ & $81,82 \%$ & $2,27 \%$ & $9,09 \%$ \\
\hline
\end{tabular}

\section{With-translation strategy in constructing a graph}

Table 1 shows that the majority of the subjects used the with-translation strategy. Graph construction with-translation strategy included the process of translating graphical representations $f$ and $g$ into symbolic representations, forming symbolic representations of the composition function then translate the symbolic representation of the composition function into a graphical form. The process of switching from one form of representation to another form of representation is called translation.

There were two types of the translation carried out by the subjects in constructing the graph of composition function, namely translation from the graph to symbolic $(\mathrm{G} \rightarrow \mathrm{S}$, Figure 1.a) and from symbolic to graph $(\mathrm{S} \rightarrow \mathrm{G}$, Figure 1.b). In the interview, the subjects admitted that the only way to construct the graph of composition function $(f \circ g)(x)$ was by knowing the formula of function $f$ and $g$ first. Here is a snippet of the interview.

I : I see you make a formula of function $f$ and $g$, why is that?

M1 : yes, because I will make a graph of composition function.

M2 : I need to know the formula $f, g$ and $(f \circ g)(x)$, then I make the graph.

The overview of the construction process with-translation strategy can be seen in Figure 3, and the description code of construction process is in Figure 4. We will analyze the activities of M1 and M2 on the two types of translation referring to the translation mechanism by Bossé, et.al., (2014) including unpacking sources, conducting preliminary coordination, constructing target and determining equivalence.

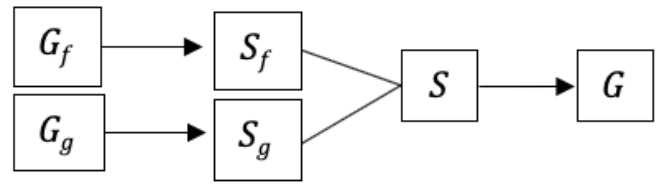

Figure 3. The graph construction process of composition function using with-translation strategy

\begin{tabular}{|c|c|c|c|c|c|}
\hline$G_{f}$ & Graph $f$ & $G_{g}$ & Graph $g$ & $S_{f}$ & Symbolic $f$ \\
\hline$S_{g}$ & Symbolic $g$ & $S$ & Symbolic $(f \circ g)(x)$ & $G$ & $\operatorname{Graph}(f \circ g)(x)$ \\
\hline - & Translation & - & Processing & & \\
\hline
\end{tabular}

Figure 4. The description code of graph construction process of composition function using translation strategy 
It needs to be underlined that this translation is done by the subjects who perceive the graph as an object consisting of points in the coordinate plane fulfilling the equation (Varberg, Purcell, \& Rigdon, 2003). The subjects do not know that the graph can be constructed using the rules of transferring some of the ordered pairs to the points on a Cartesian coordinate plane (Duval, 2006). The works of M1 and M2 on the two types of with-translation strategy are described as follows.

\section{Translation from graph $f$ to symbolic $f$ by M1}

The result of M1's work (Figure 1.a) does not show the process of making the formula $f$ of graph $f$. When the subject was asked to explain the function $f(x)=-(x+1)^{2}+5$, the following conversation ensued.

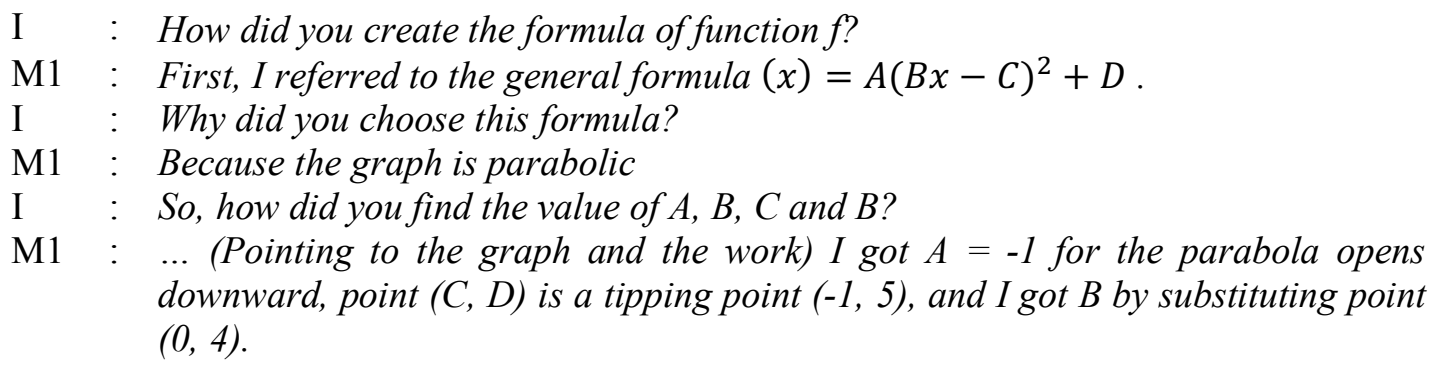
downward, point $(C, D)$ is a tipping point $(-1,5)$, and I got B by substituting point $(0,4)$.

The initial stage of translation from the graph to symbolic by M1 is to unpack the source. At this stage, M1 performed some activities including: First, identifying micro-concepts of graph $f$ namely parabolic graph, the parabola opens downward, some points on the graph are ($1,5),(0,4),(-2,4)$ and $(1,1)$, and graph cut the $x$-axis. The construction of graph refers to the effort to find graph micro-concepts of the various sources available such as symbolic, graphs, tables or description of the real situation and articulating the mathematical relationship from microconcepts to source and graph representations so that it can be graphed. The attempts to find a graph micro-concept depend on the type of sources representation (Adu-Gyamfi, Stiff, \& Bossé, 2012). Second, classifying the graph identifiers which were prominent and which were not. Information of parabolic graph, turning downward parabola, the turning point $(-1,5)$ and point (0.4) were the key elements. Third, M1 admitted that the key elements could help to get the formula of function $f$. M1 tried to synthesize the meaning of the key elements. Here are excerpts of the interview:

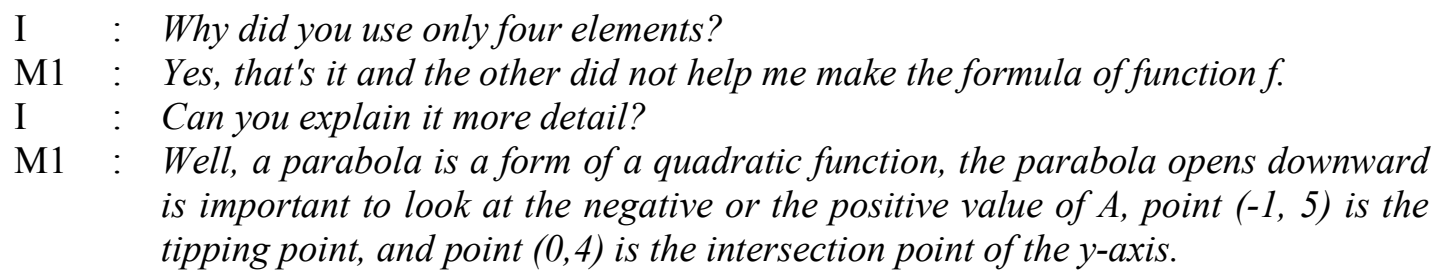
is important to look at the negative or the positive value of $A$, point $(-1,5)$ is the tipping point, and point $(0,4)$ is the intersection point of the $y$-axis.

In the preliminary coordination, $\mathrm{M} 1$ had investigated the micro-concept of function $f$ formula (symbolic representation) based on the result of unpacking source. Then M1 created a mapping between the key micro-concept on the graph and symbolic. In the target construction stage, M1 transferred micro-concept of graph $f$ to the general concept form of a quadratic function by substituting the value of $\mathrm{A}, \mathrm{C}$, and D to the common form. After that, M1 chose one 
point $(0,4)$ to be substituted into the last formula so that value B could be obtained and $f(x)=$ $-(x+1)^{2}+5$ was obtained. To find out M1's argument on the results, the following conversation occurred.

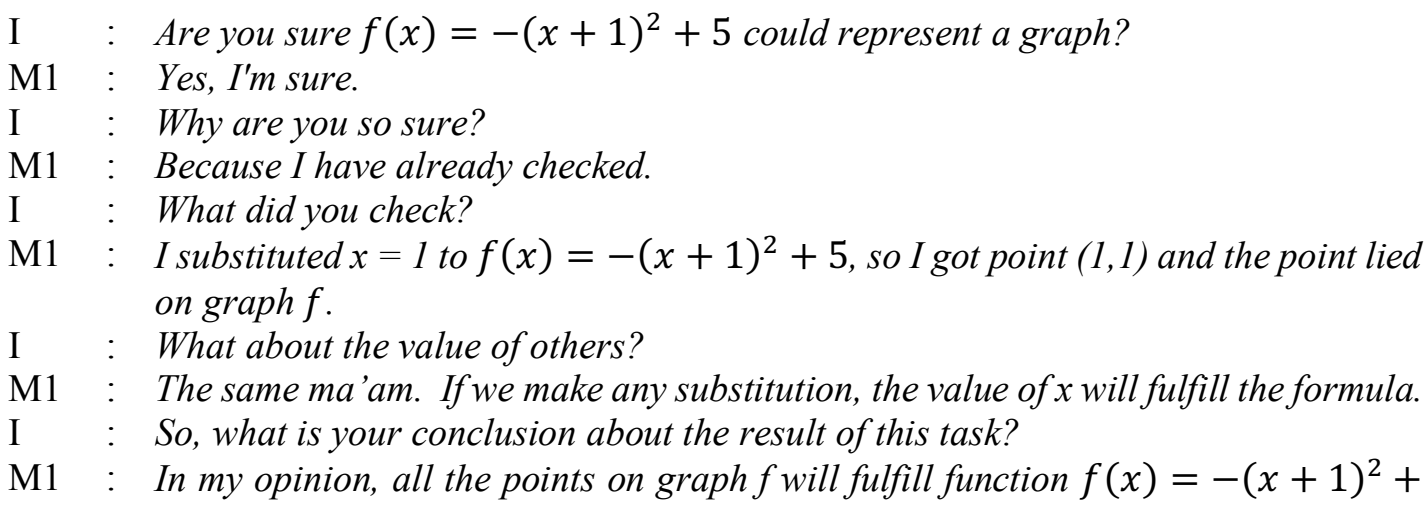
5 .

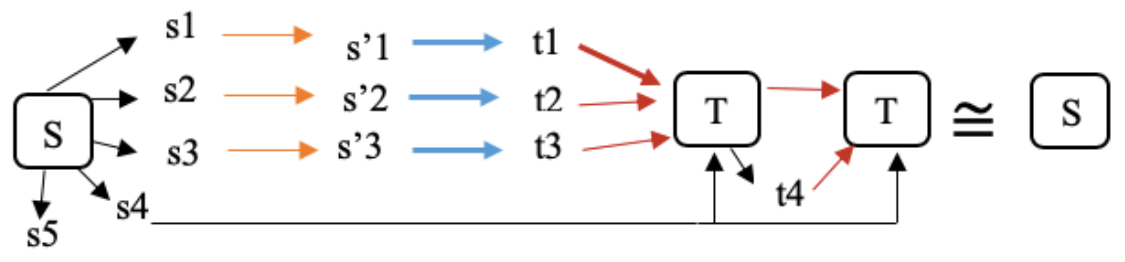

Figure 5. The structure of M1's cognitive process in translation from graph $f$ to symbolic $f$

\begin{tabular}{|c|c|c|c|c|c|}
\hline $\mathrm{s}$ & Graph $f(x)$. & $\mathrm{T}^{\prime}$ & $f(x)=-(B x+1)^{2}+5$ & $\mathrm{~T}$ & $f(x)=-(x+1)^{2}+5$ \\
\hline$\cong$ & Equivalence & s1 & The graph is parabolic & s'2 & Parabola opens downward \\
\hline & Identifying & s2 & $\begin{array}{l}\text { The direction of opening } \\
\text { the parabola }\end{array}$ & s'3 & $(-1,5)$ is tipping point \\
\hline & Mapping & s3 & Point $(-1,5)$ & $\mathrm{t} 1$ & $f(x)=A(B x-C)^{2}+D$ \\
\hline$\longrightarrow$ & $\begin{array}{l}\text { Transferring of } \\
\text { content }\end{array}$ & s4 & $\begin{array}{l}\text { Point }(0,4) \text {, } \\
(-2,4),(1,1)\end{array}$ & t2 & $A=-1$ \\
\hline & Substituting & s5 & $\begin{array}{l}\text { Graph intersection of the } \\
y \text {-axis }\end{array}$ & t3 & $C=-1 \& D=5$ \\
\hline$\longrightarrow$ & Constructing & s'1 & The quadratic function & t4 & $\mathrm{B}=1$ \\
\hline
\end{tabular}

Figure 6. The description code of M1's structure of cognitive process in translation from graph $f$ to symbolic

Substituting the value of $x$ to $f(x)=-(x+1)^{2}+5$ was a step performed by M1 to determine the equivalence between graph and symbolic. M1 was also able to conclude that either graph or symbolic presents result in the same concept, a quadratic function. Based on the description, the M1's structure of cognitive processes based on the stage of translation process graph $f$ into symbolic is presented in Figure 5. The code description of M1's structure of cognitive processes is in Figure 6. 


\section{Translation from graph $f$ to symbolic $f$ by M2}

The initial stage of translation from the graph to symbolic by M2 is unpacking source. At this stage, M2 identified several micro-concepts on graph $f$ namely parabolic, the parabola opens downward and point (-1.5). M2 ensured that the three micro-concepts were micro-concepts that were prominent in graph $f$. He also confirmed that there were other micro-concepts such as other points on the graph and two intersection points with $x$-axis, but they are all not useful to M2 in making the symbolic $f$. Furthermore, M2 explained that the graph in a parabola-shaped graph was quadratic function graph and point (-1.5) was the tipping point or maximum point of parabola. M2 did preliminary coordination by investigating micro-concept of symbolic representation $f$. It is illustrated in the following conversation.

I : How do you take advantage of the information on the graph to create formula f?

M1 : Here (pointing to his work), the parabolic-shaped graph means the function is in the form $f(x)=x^{2}$. It is a quadratic function with the tipping point $(0,0)$.

I : Is this $f(x)=x^{2}$ open upward?

M1 : Yes, if $f(x)=x^{2}$ is reflected on $x$-axis, it will open downward, so $f(x)=x^{2}$ is changed as $f(x)=-x^{2}$

I : What did you check?

M1 : I substituted $x=1$ to $f(x)=-(x+1)^{2}+5$., so I got point $(1,1)$ and the point lied on $\operatorname{graph} f$.

I : And then?

M1 : The tipping point in the graph is (-1.5). It means $f(x)=-x^{2}$ is moved one unit to the left and five units to the top. Thus, it is obtained $(x)=-(x+1)^{2}+5$.

Based on the above conversation, it could be illustrated that M2 mapped micro-concept on a graph using the micro-concept on quadratic function formula. M2 constructed a symbolic representation of function $f$ (target representation) by transferring the content of micro-concept graph to the micro-concept of symbolic representation in accordance with the mapping in the stage of preliminary coordination. Referring to the interview and the work of M2, the activity of M2 at the stage of constructing target can be seen. Transferring from graph shape namely parabola to quadratic function formula raised a formula $f(x)=x^{2}$ where graph $f(x)=x^{2}$ had a characteristic namely open upward and maximum point in $(0,0)$. Next, since graph $f$ opened downward, $f(x)=x^{2}$ was reflected on $x$-axis to obtain $f(x)=-x^{2}$. The tipping point of the graph was $f(x)=-x^{2}$ in (0.0), while the point of graph $f$ was in (-1.5). Therefore, M2 shifted $f(x)=-x^{2}$ one unit to the left and five units to the top and it obtained the symbolic representation of $f$ in the form of $f(x)=-(x+1)^{2}+5$.

In the interview, M2 explained that after getting formula $f$ he did not perform checking on the equivalence of graph and symbolic generated. However, he believed that the two representations were equal. Thus, M2 did not try to substitute an $x$ value to $f(x)=-(x+1)^{2}+$ 5 and matched it with a point on the graph to determine the equivalence of both representations. This finding was reinforced by the absence of activity related to the examination of equality in both representations (symbolic and graphs). Adu-Gyamfi et al., (2012) classify negligence determine equality of representation into one type of error for their missing element in the translation process. These findings indicated that the absence or not optimal in determining equity activity was a sign of the emergence of pseudo-thinking in translation (Sa'dijah, Afriyani, Subanji, Muksar \& Anwar, 2014). 


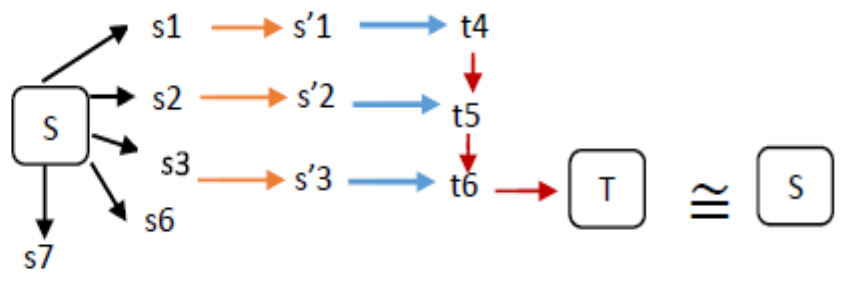

Figure 7. The structure of M2's cognitive process in translation from graph $f$ to symbolic

\begin{tabular}{|c|c|c|c|c|c|}
\hline $\mathrm{S}$ & Graph $f$ & s1 & The graph is parabolic & $\mathrm{T}$ & $f(x)=-(x+1)^{2}+5$ \\
\hline & Identifying & s2 & $\begin{array}{l}\text { The direction of } \\
\text { opening the parabola }\end{array}$ & s'2 & Parabola opens downward \\
\hline & Mapping & s3 & Point $(-1,5)$ & s'3 & $(-1,5)$ is tipping point \\
\hline$\rightarrow$ & $\begin{array}{l}\text { Transferring of } \\
\text { content }\end{array}$ & s6 & $\begin{array}{l}\text { Graph intersection of } \\
\text { the } \mathrm{x} \text {-axis }\end{array}$ & $\mathrm{t} 4$ & $f(x)=x^{2}$ \\
\hline$\longrightarrow$ & Constructing & s7 & $\begin{array}{l}\text { Graph intersection of } \\
\text { the y-axis }\end{array}$ & $\mathrm{t} 5$ & $\begin{array}{l}\mathrm{f}(\mathrm{x})=\mathrm{x}^{2} \text { is reflected on } \\
\text { the } \mathrm{x} \text {-axis }\end{array}$ \\
\hline$\cong$ & Equivalence & s'1 & $\begin{array}{l}\text { The quadratic } \\
\text { function }\end{array}$ & t6 & $\begin{array}{l}f(x)=-x^{2} \text { one unit to } \\
\text { the left and five units to } \\
\text { the top }\end{array}$ \\
\hline
\end{tabular}

Figure 8. The description code of M2's structure of cognitive process in translation from graph $f$ to symbolic

In this with-translation strategy, we encounter the presence of the phenomenon of pseudotranslation thinking. However, this article does not discuss the characteristics of pseudotranslational thinking. Therefore, investigating the characteristics of pseudo-translational thinking could be extended as future research. M2's structure of cognitive process based on the stage of the graph $f$ translation process into symbolic is presented in Figure 7. The code description of the thinking structure is in Figure 8.

\section{Translation from graph $g$ to symbolic $g$ by M1}

In unpacking source (graph $g$ ) stage, M1 did: First, observing the shape of the graph namely a straight line, identifying points on graph $g$, i.e., $(-1,1)(-2,2)(-3,3)(-4,4),(0,1),(1,2),(2,3)$ and $(3,4)$ and identifying the leap $g$ at $x=0$. According to Adu-Gyamfi and Bossé (2013), M1 have an understanding of the register graph marked by the ability to recognize some of the characters and specific conventions for graphs. Second, realizing what he had previously identified is a key micro-concept on graph $g$. Third, identifying a leap of the graph at $x=0$ which indicates that the domain graph $g$ was divided into two conditions. In the preliminary coordination stage, M1 investigated the association between the value of the abscissa and ordinate so that he got the formula of function $g$. He discovered the ordinate value was the absolute value of abscissa value. It was valid for $x$ negative, while for $x$ positive the provision of ordinate value was equal to the abscissa value plus 1 . The result of the investigation was used to build the target representation by transferring into symbolic form namely $g(x)=|x|$ for $x<0$ and $g(x)=x+1$ for $x \geq 0$. Based on 
the interview, M1 admitted that he did not check the symbolic $g$ representation that he got. The reason is described in the following interview.

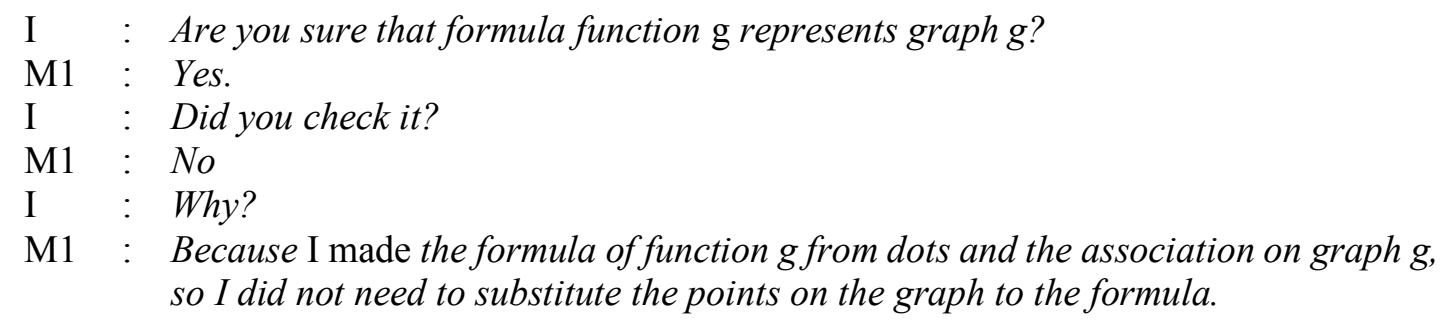

\section{Translation from graph $g$ to symbolic $g$ by M2}

In the stage of unpacking source, M2 also identified micro-concept of graph $g$ as what M1 did and he also realized that a micro-concept was an important element to build a representation of the source. M2 conducted preliminary coordination by investigating micro-concept of target representation builder associated with micro-concept he had previously identified. M2 made an association between the graph leap at $x=0$ with domain function $g$ implicating on two domain conditions, namely $x<0$ and $x \geq 0$. The association between the abscissa value and the ordinate on $x$ negative axis implied that the ordinate value was negative from abscissa values and for the positive $x$-axis, the ordinate value represented the abscissa value plus 1 . The result of this coordination was used to construct a symbolic representation of the form $g(x)=-x$ for $x<0$ and $g(x)=x+1$ for $x \geq 0$.

\section{Translation from symbolic $(f \circ g)(x)$ to graph $(f \circ g)(x)$ by M1 and M2}

M1 and M2 constructed graph of composition function $(f \circ g)(x)$ after making a symbolic representation $(f \circ g)(x)$. M1 and M2 outlined $(f \circ g)(x)=f(g(x))$, then they entered $g(x)=-x$ or $g(x)=|x|$ as the domain of $f(x)$ for $x<0$ and $g(x)=x+1$ for $x \geq 0$. Thus, the result was

$$
\begin{gathered}
f o g(x)=f(-x)=-(-x+1)^{2}+5 \text { for } x<0 \text { and } \\
f o g(x)=f(x+1)=-(-x+1+1)^{2}+5 \text { for } x \geq 0
\end{gathered}
$$

Furthermore, they constructed a graph based on the symbolic representation of $(f \circ g)(x)$. Based on the results of works M1's and M2's (Figure 1.a and Figure 1.b), we produced the indicators of the translation process of symbolic representation to a graph of the composition function ( $f o$ $g)(x)$ as shown in Table 2.

Table 2. The indicators of the translation process from symbolic to graph

\begin{tabular}{ll}
\hline \multicolumn{1}{c}{ Translation stages } & \multicolumn{1}{c}{ Indicators } \\
\hline Unpacking source: & - Identifying the type of $(f \circ g)(x)$ \\
$\begin{array}{l}\text { Determining the micro-concept of } \\
\text { source representation, }\end{array}$ & - Identifying the domain of $(f \circ g)(x)$ \\
separating micro-concept that is & - Identifying the coefficient value of $x^{2}$ \\
relevant and not relevant and & Identifying the symmetry of $(f \circ g)(x)$ \\
\hline
\end{tabular}




\section{Translation stages}

synthesizing the meaning of microconcept of source representation

\section{Preliminary coordination:} Identifying and articulating the same mathematical relationship of micro-concept on the representation of the source and target, making the network idea that illustrates the association inter representation

\section{Constructing target} representation: Forming a target representation using a suitable micro-concept through transferring the content of micro-concept of source representation to the microconcept of target representation

Determining equivalence: determining representational equivalence by considering ideas between the two representations

\section{Indicators}

- Identifying that $(f o g)(x)$ is a linear combination of quadratic forms and constants

- Setting the type of function, the domain function, the coefficient value of $x^{2}$ as a micro-concept that is relevant to create a graph

- Stating that $(f \circ g)(x)$ is a quadratic function because the highest rank of $\mathrm{x}$ is two.

- Stating that $(f \circ g)(x)$ has two domain conditions and at $x$ $=0$ there is a leap

- Stating the coefficient value of $x^{2}$ is negative

- Creating a relationship between $(f \circ g)(x)$ as a quadrate function and the graph shape namely parabola.

- Making the relationship between the coefficient value 5 that is negative and the parabola opening downward.

- Making the connection between leap at $x=0$ and a full circle at the point of intersection of y-axis graph fo $g(x)=-(x+2)^{2}+5$ and the empty circle on the point of intersection of $y$-axis graph $f o g(x)=-(-x+$ $1)^{2}+5$

- Preparing some values of $x$ namely $-2,-1,0,1,2$ to be substituted to $(f \circ g)(x)$.

- Substituting the value of $\mathrm{x}$ that has been prepared before to $(f \circ g)(x)$ and it is obtained the ordered pairs $(0,1),(1$, $-4),(2,-11),(-1,1),(-2,-4),(0,4)$

- Making a vertical line and horizontal line

- Labeling $x$ on the horizontal line and called it as the $x$-axis

- Labeling y on the vertical line and called it as the y-axis

- Making a scale on both axes of Cartesian coordinates

- Plotting the points $(0,1)(1,-4,(2,-11),(-1,1),(-2,-4)$ and (0.4) in Cartesian coordinates

- Making a smooth curve connecting points $(0,1),(1,-4)$ and $(2,-11)$

- Making a full circle to the point $(0,1)$

- Making a smooth curve connecting points $(0,4),(-1,1)$ and $(-2,-4)$.

- Creating an empty circle at point $(0,4)$

- Labeling $(f \circ g)(x)$ on a parabolic curve that has been made

- Checking the correctness in plotting the points on a Cartesian coordinate

- Determining the value $(f \circ g)(0)$ by substituting the value $x=0$ to $f \circ g(x)=-(x+2)^{2}+5$ and it is obtained 1

- Determining the value $(f \circ g)(0)$ by looking at the graph $(f \circ g)(x)$ and $(0, f \circ g(0)=(0,1)$

\section{The without-translation strategy to construct graph}

Only a few students who constructed a graph using a without-translation strategy (see Table 1) and only one of them successfully constructed a graph namely M3. M3's work can be seen in Figure 2. In contrast to the with-translation, without-translation strategy in graph construction 
does not go through the stage of making the formula of the graph function. The cognitive process in constructing a graph involving various concepts belongs to a conceptual understanding (Anderson \& Krathwohl, 2014). M3 understood that plotting points on Cartesian coordinate axes could create the graph. M3 could read the ordered pair (domain, range) of the composition function of graph $f$ and $g$. In other words, M3 understood the composition function as a mapping of the input value set (function $g$ ) to output value set $(f(g(x))=(f \circ g)(x))$. M3 considered inputoutput association, so he constructed a graph by shifting graph $f$ to the left as far as one unit and a graph reflection $f$ to $y$-axis. M3's structure of cognitive process in constructing the graph of composition function is presented in Figure 9.

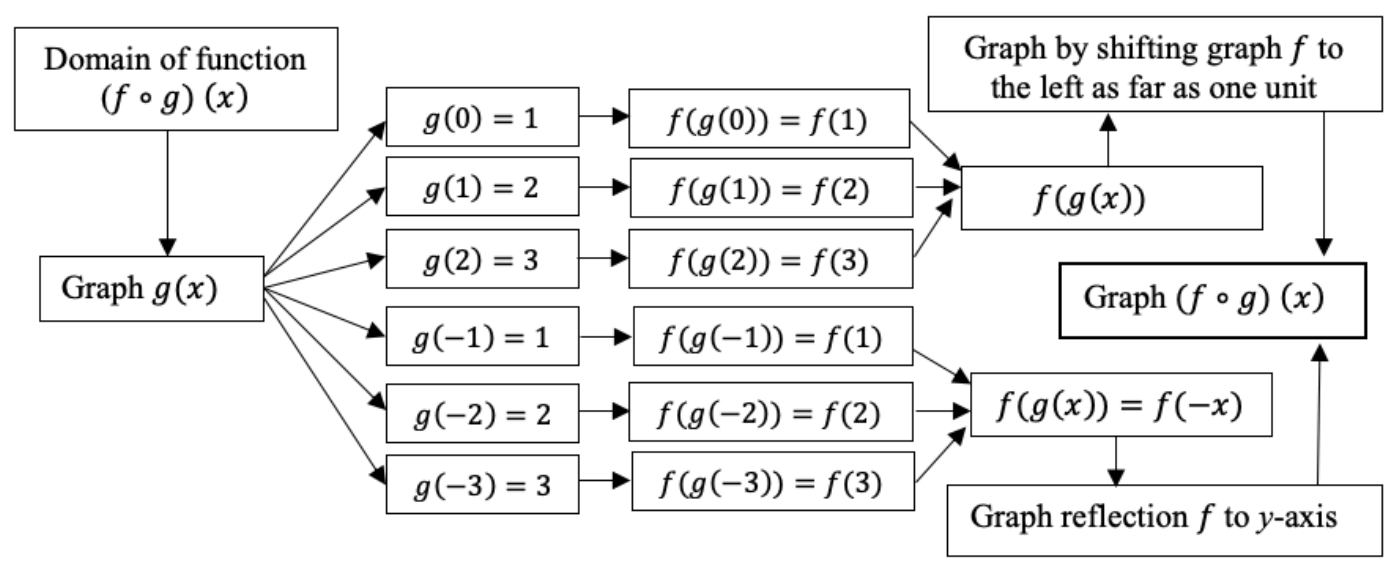

Figure 9. Thinking structure of M3 in constructing graph $(f \circ g)(x)$

Although the steps in the without-translation strategy are shorter than using the withtranslation, it cannot be concluded that without-translation is better than with-translation. To conclude which strategy is better, it is necessary to explore the quality of PMTs' mathematical understanding in each strategy. In with-translation strategy, the subjects construct graphs through symbolic representations. The activities carried out by M1 and M2 at the preliminary coordination stage are very different. M1 is more likely to map the micro-concept of source representation to the micro-concept of target representation, whereas M2 is more likely to map the meaning of the micro-concept of source representation to the appropriate micro-concept of target representation. Referring to the finding of Adu-Gyamfi and Bossé (2013), M1's activities on preliminary coordination stage are classified as fact mapping, while M2's activities are concept mapping.

In without-translation strategy, M3 construct graphics by relying on the concept of graph transformation, so that the subject only interacts with the graph. The differences in cognitive processes carried out by M1, M2, and M3 are parameters of differences in the quality of understanding subjects have in each graph construction strategy (Barmby et al., 2007). Therefore, a search for the quality of student understanding for each strategy is deemed necessary, and this is a recommendation for further research.

In with-translation strategy, there are differences in subjects' activities in transferring the contents of micro-concepts of source representation to micro-concepts of target representation. These activities occurred at the stage of constructing the target representation. The content of the micro-concepts transferred by M1 in the form of micro-concepts is considered important, while the contents of the micro-concepts transferred by M2 are mathematical meanings 
represented by key micro-concepts of source representation. For example, M1 substituted several points on the parabolic graph to the formula $f(x)=A(B x-C)^{2}+D$. M2 transferred graph which opened downward and $f(x)=x^{2}$ was reflected on the $x$-axis in order to have $f(x)=(-$ $x)^{2}$. It happens because there is a variety of mapping at the stage of coordination preliminary. Here, the transfers made by M1 are called direct transfers, whereas those carried out by M2 are called indirect transfers. Referring to Nicaud, Bouhineau, and Gélis (2001), cognitive process in direct transfers are classified as syntactic construction meanwhile in indirect transfers are classified as semantic construction.

The graph construction tasks in this research have limitations to assess translation strategy involving the table and verbal representations since the construction of graph in the current research involves symbolic and graphical representations. In addition to the use of GCT, which emphasize the representations, Bossé, Adu-Gyamfi, and Cheetam (2011) argue that translation' difficulties relate to the used representations. The results of this research have implications for the realignment of the composition function learning plan, so that prospective mathematics teachers can understand the function of composition presented in various forms of mathematical representation. The recommended learning for lecturers to develop the cognitive process of PMTs is by designing tasks to construct graphs of non-routine composition functions such as GCT.

\section{Conclusion}

This article describes the strategies and cognitive process of PMTs in constructing the graph of composition function. We found two strategies, namely with-translation and withouttranslation, in constructing a graph. We identified two types of the translation, i.e., translation from the graph to symbolic $(\mathrm{G} \rightarrow \mathrm{S})$ and from symbolic to graph $(\mathrm{S} \rightarrow \mathrm{G})$. In with-translation strategy, the cognitive process in constructing the graph begins with translating the graphs $f$ and $g$ into symbolic forms, making symbolic functions of the composition $f$ and $g$, and then end with symbolically translating the composition function into a graph. This translation strategy flow is thought to be caused by the PMTs learning experience that is accustomed to constructing graphs of functions presented in the form of symbolic representations. In this case, there is a transferring variation of the micro-concept of source representation to micro-concept of target representation, i.e., direct and indirect transfers. Direct transfer is the transfer of the contents of the microconcept of source representation to the micro-concept of target representation, while the indirect transfer is to interpret the contents of the micro-concept of source representation first after it is transferred to the micro-concept of target representation. The cognitive process in withouttranslation strategy is done by finding a micro-concept of composition function graph builders directly on graph $f$ and $g$. Micro-concepts are in the form of ordered pairs (domain, range), inputoutput association, and convention between the horizontal axis ( $x$-axis) and the vertical axis $(y$ axis).

The reason PMTs chose a without-translation strategy is that this strategy is more concise than another strategy. PMTs assume that to construct a graph, it is enough to determine the coordinate points and connect those points to sketch a smooth curve. The type of representation and function used in GCT is considered to influence the cognitive process of PMTs in construction of a graph. In this circumstance, follow-up research is encouraged to investigate the cognitive process of PMTs in completing GCT, which involves verbal representation or other representations on the functions. 


\section{References}

Adu-Gyamfi, K., \& Bossé, M. J. (2013). Processes and reasoning in representations of linear functions. International Journal of Science and Mathematics Education, 12(1), 167-192. Doi: 10.1007/s10763013-9416-x

Adu-Gyamfi, K., Stiff, L., \& J. Bossé, M. (2012). Lost in translation: Examining translation errors associated with mathematical representations. Schools Sciences and Mathematics, 112(3), 159-170. Doi: $10.1111 / \mathrm{j} .1949-8594.2011 .00129 . x$

Anderson, L.W., \& Krathwohl, D.R. (2014). Kerangka landasan untuk pembelajaran, pengajaran, dan asesmen: Revisi Taksonomi Bloom. Jakarta: Pustaka Belajar.

Barmby, P., Harries, T., Higgins, S., \& Suggate, J. (2007). How can we assess mathematical understanding? Proceedings of the 31st Conference of the International Group for the Psychology of Mathematics Education, 1, 41-48.

Bossé, M. J., Adu-Gyamfi, K., \& Cheetam, M. R. (2011). Assessing the difficulty of mathematical translations: Synthesizing the literature and novel findings. International Electronic Journal of Mathematics Education, 6(3), 113-133.

Bossé, M. J., Adu-Gyamfi, K., \& Chandler, K. (2014). Students' differentiated translation processes. International Journal for Mathematics Teaching and Learning, 1-28. Retrieved from http://www.cimt.org.uk/journal/bosse5.pdf

Carlson, M. P., Larsen, S., \& Jacobs, S. (2001). An investigation of covariational reasoning and its role in learning the concepts of limit and accumulation. Proceedings of the Twenty-Third Annual Meeting of the North American Chapter of the International Group for the Psychology of Mathematics Education. Retrieved from https://math.la.asu.edu/ carlson/Publications/covar.pdf

Creswell, J. W. (2012). Educational research: Planning, conducting, and evaluating quantitative and qualitative Research (4ed.). Lincoln: Library of Congress Cataloging-in-Publication Data.

Diezman, C. M., \& Tom, L. (2006). Primary students' knowledge of and errors on number lines. Paper presented in the 29th Annual Conference of the Mathematics Education Research Group of Australasia, Canbera. Retrieved from http://www.merga.net.au/publications/conf.php

Duval, R. (2006). A cognitive analysis of problems of comprehension in a learning of mathematics. Educational Studies in Mathematics, 61(1), 103-131. Doi: 10.1007/s10649-006-0400-z

Elia, I., \& Spyrou, P. (2006). How students conceive function: A triarchic conceptual-semiotic model of the understanding of a complex concept. The Mathematics Enthusiast, 3(2), 256-272.

Friel, S. N., Curcio, F. R., \& Bright, G. W. (2001). Making sense of graphs: Critical factors influencing comprehension and instructional implications. Journal for Research in Mathematics Education, 32(2), $124-158$.

Goldin, G. A. (1998). Representational systems, learning, and problem solving in mathematics. Representations and the Psychology of Mathematics Education: Part II, 17(2), 137-165. Doi: 10.1016/S0364-0213(99)80056-1

Higley, K. (2009). Measuring knowledge of mathematical functions: Validity of scores and profiles of participants (Doctoral dissertation). The Pennsylvania State University. Retrieved from https://etda.libraries.psu.edu/files/final_submissions/3425

Jojo, Z. (2014). Mental constructions formed in the conceptual understanding of the chain rule. Mediterranean Journal of Social Sciences, 5(1), 171-179.

Lowrie, T., \& Carmen M., D. (2007). Middle school students' interpreting graphical tasks: Difficulties within a graphical language. Paper presented in the 4th East Asia Regional Conference on Mathematics Education, Penang, Malaysia. Retrieved from http://www.csu.edu.au/research/glim/downloads/TL_CD_EARCOME4.pdf

Morden-Snipper, D. R., Dai, T., Booth, J. L., Chang, B. L., Cromley, J. G., \& Newcombe, N. S. (2015). Cognitive factors and representation strategies in sketching math diagrams. Paper presented at the 37 th Annual Meeting of the Cognitive Science Society. Philadelphia, PA.

NCTM. (2001). Representation: An Important Process for Teaching and Learning Mathematics. Principles and standards. Reston, Virginia: NCTM.

Nicaud, J., Bouhineau, D., \& Gélis, J. (2001). Syntax and semantics in algebra. Paper presented at the 12th ICMI Study Conference. Retrieved from https:/hal.archives-ouvertes.fr/hal00962023/document. 
Roth, W.-M., \& Bowen, G. M. (2001). Professionals read graphs: A semiotic analysis. Journal for Research in Mathematics Education, 32(2), 159-194. Doi: 10.2307/749672

Ruchti, W.P. \& Bennett, C.A. (2013). Develop reasoning through pictorial representations. Mathematics Teaching in the Middle School, 19(1), 30-36. Doi: 10.5951/mathteacmiddscho.19.1.0030

Sa'dijah, C., Afriyani, D., Subanji, S., Muksar, M., \& Anwar, L. (2014). Assessing students' pseudomathematical translation using translation-verification model. AIP Conference Proceedings, 2014(1), 1-8. Doi: 020144-1

Shah, P., \& Hoeffner, J. (2002). Review of graph comprehension research: Implications for instruction. Educational Psychology Review, 14(1), 47-69. Doi: 10.1023/A:1013180410169

Subanji. (2007). Proses berpikir pseudo penalaran kovariasional mahasiswa dalam mengonstruksi grafik fungsi kejadian dinamik (Disertasi). Universitas Negeri Surabaya, Surabaya.

Varberg, D., Purcell, E. J., \& Rigdon, S. E. (2003). Calculus (8th edition). Prentice Hall.

Watson, A., \& Harel G, G. (2013). The role of teachers' knowledge of functions in their teaching: A conceptual approach with illustrations from two cases. Canadian Journal of Science Mathematics and Technology Education, 13(2), 154-168. Doi: 10.1080/14926156.2013.784826 